\title{
PENGARUH MOTIVASI, DISIPLIN, DAN LINGKUNGANKERJA TERHADAP KINERJA PEGAWAI DINAS PENDIDIKAN KOTA PALU
}

\author{
Abd. Azis ${ }^{1}$, Albar Alaydrus ${ }^{2}$ \\ (Dosen Fakultas Ekonomi Universitas Alkhairaat)
}

\begin{abstract}
ABSTRAK
Penelitian ini mengungkapkan pengaruh motivasi, disiplin dan lingkungan kerja terhadap kinerja pegawai Dinas Pendidikan Kota Palu. Tujuan yang ingin dicapai dalam penelitian ini untuk mengetahui pengaruh motivasi, disiplin dan lingkungan kerja terhadap kinerja pegawai Dinas Pendidikan Kota Palu. Metode yang digunakan Penelilti bersifat verifikatif dengan alat bantu koesioner terhadap 42 responden. Hasil penelitian ini membuktikan bahwa melihat hubungan antara ketiga variabel bebas motivasi, disiplin dan lingkungan kerja terhadap kinerja pegawai Dinas Pendidikan Kota Palu sebesar 0,886 artinya hubungan variabel bebas (independen) terhadap variabel terikat (dependen) adalah sangat kuat. $\mathrm{R}$ Square atau koefisien determinasi $\left(\mathrm{R}^{2}\right)$ adalah melihat pengaruh antara variabel motivasi, disiplin dan lingkungan kerja terhadap kinerja pegawai Dinas Pendidikan Kota Palu sebesar 0,786 atau 78,6\% artinya pengaruh variabel bebas (independen) terhadap variabel terikat (dependen) sebesar $78,6 \%$ sedangkan sisanya $21,4 \%$ adalah pengaruh variabel lain yang tidak diteliti dalam penelitian ini.
\end{abstract}

Kata Kunci: Motivasi, Disiplin, Lingkungan Kerja dan Kinerja.

\section{LATAR BELAKANG}

Dinas Pendidikan Kota Palu mempunyai tugas pokok merumuskan kebijakan teknis dan melaksanakan kegiatan teknis operasional di bidang pelayanan dan pendidikan dan melakukan pengawasan,atau pengendalian serta evaluasi pelaporan penyelenggaraan di bidang pendidikan yang meliputi data dan informasi, pengelolaan pelayanan pendidikan khususnya di Kota Palu.

Saat ini, kinerja pegawai pada Dinas Pendidikan Kota Palu masih belum bisa dikatakan optimal. Artinya masih terdapat kendala-kendala yang dihadapi.Pada dasarnya hambatan terbesar kinerja pegawai Dinas Pendidikan Kota Palu terletak pada individu dan kemampuan pegawai itu sendiri. Ini berdasarkan hasil observasi peneliti sementara ditemukan bahwa kebanyakan pegawai Dinas Pendidikan Kota Palu kurang motivasi dalam menjalankan pekerjaannya ini menyebabkan pegawai yang terkesan kurang menunjukkan kualitas kinerjanya. Setiap pegawai yang bekerja pada Dinas Pendidikan Kota Palu sangat memerlukan adanya pemberian motivasi. Pemberian motivasi ini dapat memberikan efek positif dalam pelaksanaan kerja pegawai dalam pencapaian target kerja organisasi. Hal ini dapat dilihat dari bagaimana hubungan tersebut terjadi dalam keseharian.Pada kenyataannya terdapat dua jenis motivasi yaitu motivasi intern dan ekstern. (Moekijat, 1999:9) Pada motivasi intern dipengaruhi oleh keinginan-keinginan dan kebutuhan yang berasal dari dalam diri seseorang. Sedangkan motivasi ekstern yaitu berasal dari luar termasuk masalah-masalah hubungan kerja, gaji, kondisi kerja dan kebijakan organisasi, serta masalah-masalah isi pekerjaan, penghargaan, promosi, dan tanggung jawab. Selain itu disiplin pegawai juga adalah salah satu kendala yang mengakibatkan kinerja pegawai tidak optimal. dikernakan banyaknya pegwai yang tidak disiplin contohnya pegawai yang terlambat datang dari jam kantor yang di tentukan dan beberapa 
pegawai masih banyak dari mereka hanya berkumpul diluar kantor sebelum jam istirahat danhanya membicarakan tentang hal-hal yang tidak berkaitan dengan pekerjaanya. Hal ini mengakibatkan tidak efisiennya kerja organisasi. Disisi lain lingkungan kerja di dalam kantor pun kurang memberikan kenyaman, kepada pegawai dalam bekerja. Ruang kerja yang digunakan oleh pegawai untuk menjalankan tugas kesehariannya sangat padat dengan banyaknya meja yang berhimpitan satu sama lainnya sehingga ruang gerak pun terbatas ditambah dengan pencahayaan dalah ruang kerja yang kurang terang. Selain itu kurangnya ketepatan waktu yang digunakan oleh pegawai dalam menyelesaikan tugasnya. Hal-hal ini tentunya akan mempengaruhi kinerja yang dihasilkan.

Ungkapan masalah tersebut diatas merupakan observasi awal yang dilakukan oleh peneliti, dimana ditemukan bahwa kinerja pegawai di kantor Dinas Pendidikan Kota Palu masih dalam kategori yang rendah, hal ini dapat dibuktikan dengan kualitas, kuantitas dan ketepatan waktu dalam menyelesaikan pekerjaannya, seperti penerbitan surat keputusan yang seringkali tidak sesuai dengan target yang telah ditentukan. Namun dibalik itu, kinerja yang belum maksimal ini turut dipengaruhi oleh motivasi kerja, motivasi kerja selayaknya diberikan kepada pegawai, dimulai dari hal-hal yang kecil seperti pujian, penghargaan, sampai pada pemberian insentif bagi pegawai yang kinerjanya baik. Namun itu semua tidak diberlakukan oleh pimpinan pegawai yang bersangkutan, semua pekerjaan dilaksanakan apa adanya, dengan ketentuan masing-masing, tanpa ada inovasi untuk menaikan kinerja pegawai tersebut.

Dari berbagai masalah dan kendala inilah membuat saya selaku peneliti tertarik untuk meneliti penelitian dengan judul "Pengaruh Motivasi, Disiplin dan Lingkungan Kerja Terhadap Kinerja pegawai Dinas Pendidikan Kota Palu"

\section{Rumusan Masalah}

Berdasarkan latar belakang pemikiran yang telah di paparkan, maka dengan hal-hal yang akan di jadikan pengkajian atau penelitian adalah sebagai berikut.

1. Apakah variabel Motivasi secara persial berpengaruh signifikan terhadap kinerja pegawai Dinas Pendidikan Kota Palu?

2. Apakah variabel Disiplin secara persial berpengaruh signifikan terhadap kinerja pegawai Dinas Pendidikan Kota Palu?

3. Apakah Variabel lingkungan kerja secara persial berpengaruh signifikan terhadap Kinerja pegawai Dinas Pendidikan Kota Palu?

4. Apakah variabel Motivasi, Disiplin dan Lingkungan kerja secara serempak berpengaruh signifikan terhadap kinerja pegawai Dinas Pendidikan Kota Palu?

\section{KAJIAN PUSTAKA \\ Motivasi}

Motivasi adalah "pemberian dorongandorongan individu untuk bertindak yang menyebabkan orang tersebut berperilaku dengan cara tertentu yang mengarah pada tujuan" (Ivan Aries dan Iman Ghozali, 2006). Motivasi merupakan dorongan terhadap serangkaian proses perilaku manusia pada pencapaian tujuan sedangkan elemen yang terkandung dalam motivasi meliputi unsur membangkitkan mengarahkan, menjaga, menunjukan, intensitas, bersifat terus menerus dan adanya tujuan (Wibowo, 2010).

Motivasi kerja menurut Gibson (1997) adalah kekuatan yang mendorong seorang karyawan yang menimbulkan dan mengarahkan perilaku. Motivasi merupakan hasrat di dalam seseorang yang menyebabkan orang tersebut melakukan tindakan. Motivasi kerja diartikan sebagai keadaan dalam diri individu yang mendorong keinginan individu untuk melakukan kegiatan- kegiatan tertentu guna untuk mencapai tujuan.

Menurut (Gulom, 2019) Motivasi memiliki komponen dalam dan luar, komponen dalam ialah perubahan dalam diri seseorang, keadaan merasa 
tidak puas, ketegangan psikologis. Sedangkan komponen luar adalah apa yang diinginkan seseorang dan tujuan yang menjadi arah tingkah lakunya. Jadi komponen dalam adalah kebutuhankebutuhan yang ingin dipuaskan sedangkan komponen luar adalah tujuan yang hendak dicapai. Motivasi ialah suatu model dalam menggerakkan dan mengarahkan para karyawan agar dapat melaksanakan tugasnya masing-masing dalam mencapai sasaran dengan penuh kesadaran, kegairahan dan bertanggung jawab. Jadi motivasi kerja adalah sesuatu yang menimbulkan semangat atau dorongan kerja. Oleh karena itu, motivasi kerja dalam psikologi biasa disebut pendorong semangat kerja (Sidanti, 2015).

Motivasi adalah serangkaian sikap dan nilai-nilai yang mempengaruhi individu untuk mencapai hal yang spesifik dengan tujuan individu (setiawan, 2013)

$$
\text { Indikator motivasi menurut Syahyuti }
$$

1) Dorongan untuk mencapai tujuan

Seseorang yang mempunyai motivasi yang tinggi maka dalam diri mempunyai dorongan yang kuat untuk mencapai kinerja yang maksimal, yang nantinya akan berpengaruh terhadap tujuan dari suatu bank atau instansi.

2) Semangat kerja

Semangat kerja sebgai keadaan psikologis yang baik apabila semangat kerja tersebut menimbulkan kesenangan yang mendorong seseorang untuk bekerja lebih giat dan lebih baik serta konsekuen dalam mencapai tujuan yang ditetapkan oleh perusahaan atau instansi.

3) Inisiatif

Inisiatif diartikan sebagai kekuatan atau kemampuan seseorang karyawan atau pegawai untuk memulai atau meneruskan suatu pekerjaan dengan penuh energy tanpa ada dorongan dari orang lain atau atas kehendak sendiri.

4) Rasa tanggung jawab

Sikap individu pegawai yang mempunyai motivasi kerja yang baik harus mempunyai rasa tanggung jawab terhadap pekerjaan yang mereka lakukan sehingga pekerjaan tersebut mampu diselesaikan secara tepat waktu.

\section{Disiplin Kerja}

Menurut Simamora (1997), disiplin adalah prosedur yang mengoreksi atau menghukum bawahan karena melanggar peraturan atau prosedur. Disiplin kerja adalah suatu alat yang digunakan para manajer untuk berkomunikasi dengan karyawan agar mereka bersedia untuk mengubah suatu perilaku serta sebagai suatu upaya untuk meningkatkan kesadaran dan kesediaan seseorang menaati semua peraturan perusahaan dan norma-norma sosial yang berlaku (Rivai, 2004).

Hasibuan (2006) berpendapat bahwa kedisiplinan sebagai bentuk kesadaran dan kesediaan seseorang mentaati semua peraturan perusahaan dan norma-norma sosial yang berlaku. Jadi, dikatakan disiplin apabila karyawan sadar dan bersedia mengerjakan semua tugas dan tanggung jawabnya dengan baik. Kedisiplinan harus ditegakkan dalam suatu organisasi perusahaan. Tanpa dukungan disiplin karyawan yang baik, sulit bagi perusahaan untuk mewujudkan tujuannya. Jadi, kedisiplinan adalah kunci keberhasilan suatu perusahaan dalam mencapai tujuannya Sedangkan menurut Rusli (1991) dalam faktor-faktor yang mempengaruhi produktivitas dan disiplin kerja yaitu sikap atau tingkah laku berupa kepatuhan dan ketaatan secara sadar terhadap aturan yang berlaku dalam lingkungan kerja karena ada keyakinan bahwa dengan aturan tujuan dengan tercapai.

Menurut Soejono (2000; 67) ada beberapa indikator disiplin pegawai yaitu sebagai berikut :

1. Ketepatan waktu

Para pegawai datang ke kantor tepat waktu, tertib dan teratur,dengan begitu dapat dikatakan disiplin kerja baik.

2. Menggunakan peralatan kantor dengan baik Sikap hati-hati dalam menggunakan peralatan kantor dapat mewujudkan bahwa seseorang memiliki disiplin kerja yang baik, sehingga peralatan kantor dapat terhindar dari kerusakan. 
3. Tanggung jawab yang tinggi

Pegawai yang senantiasa menyelesaikan tugas yang dibebankan kepadanya sesuai dengan prosedur dan bertanggung jawab atas hasil kerja, dapat pula dikatakan memliki disiplin kerja yang baik.

4. Ketaatan terhadap aturan kantor

Pegawai memakai seragam kantor, menggunakan kartu tanda pengenal/identitas membuat izin bila tidak masuk kantor juga merupakan cerminan disiplin kerja yang tinggi.

\section{Lingkungan Kerja}

Menurut Nitisemito (1992) Lingkungan kerja adalah segala sesuatu yang ada disekitar para pekerja yang dapat mempengaruhi dirinya dalam menjalankan tugas-tugas dibebankan kepadanya. Dapat disimpulkan bahwa lingkungan kerja merupakan segala sesuatu yang ada disekitar karyawan pada saat bekerja, baik yang berbentuk fisik ataupun non fisik yang dapat mempengaruhi dirinya dan pekerjaanya. Menurut (Marjun, 2019) Lingkungan kerja yang berupa fisik berkaitan dengan sarana dan prasarana.Sedangkan yang berkaitan dengan non fisik atau sosial adalah kondisi kerja yaitu hubungan baik antara atasan dan bawahan atau antara sesama karyawan.

Menurut Mardiana (2005) Lingkungan kerja lingkungan dimana pegawai melakukan pekerjaannya sehari-hari. Lingkungan kerja yang kondusif memberikan rasa aman dan memungkinkan para pegawai untuk dapat berkerja optimal. Lingkungan kerja dapat mempengaruhi emosi pegawai. Jika pegawai menyenangi lingkungan kerja dimana dia bekerja, maka pegawai tersebut akan betah di tempat kerjanya untuk melakukan aktivitas sehingga waktu kerja dipergunakan secara efektif dan optimis, prestasi kerja pegawai juga tinggi. Lingkungan kerja tersebut mencakup hubungan kerja yang terbentuk antara sesama pegawai dan hubungan kerja antar bawahan dan atasan serta lingkungan fisik tempat pegawai bekerja.

Yang menjadi indikator-indikator lingkungan kerja menurut (Sedarmayanti, 2001) adalah sebagai berikut:

1) Penerangan

2) Suhu udara

3) Suara bising

4) Penggunaan warna

5) Ruang gerak yang diperlukan

6) Keamanan kerja

7) Hubungan karyawan

\section{Kinerja Karyawan}

Performance atau kinerja merupakan hasil atau keluaran dari suatu proses (Nurlaila, 2010). Menurut pendekatan perilaku dalam manajemen, kinerja adalah kuantitas atau kualitas sesuatu yang dihasilkan atau jasa yang diberikan oleh seseorang yang melakukan pekerjaan (Luthans, 2005). Kinerja merupakan prestasi kerja, yaitu perbandingan antara hasil kerja dengan standar yang ditetapkan (Dessler, 2000).

Kinerja adalah hasil kerja baik secara maupun kuantitas yang dicapai oleh seseorang dalam melaksanakan tugas sesuai tanggung yang diberikan (Mangkunegara, 2002). Kinerja karyawan sering diartikan sebagai pencapaian tugas, dimana karyawan dalam bekerja harus sesuai dengan program kerja organisasi untuk menunjukkan tingkat kinerja organisasi dalam mencapai visi, misi dan tujuan organisasi (Setiawan, 2013).

Anwar Prabu Mangkunegara (2009) mengemukakan bahwa indikator kinerja adalah

1. Kualitas

Kualitas kerja adalah seberapa baik seorang pegawai mengerjakan apa yang seharusnya di kerjakan.

2. Kuantitas

Kuantitas kerja merupakan seberapa lama seorang pegawai bekerja dalam satu hari.Kuantitas kerja ini dapat di lihat dari kecepatan kerja setiap pegawai itu masing masing.

3. Pelaksana tugas

Pelaksana tugas adalah seberapa jauh pegawai mampu melakukan pekerjaannya dengan akurat atau tidak ada kesalahan. 
4. Tanggung jawab

Tanggung jawab terhadap pekerjaan adalah kesadaran akan kewajiban pegawai untuk melaksanakan pekerjaan yang di berikan perusahaan.

\section{Hubungan Antara Variabel}

1) Pengaruh Motivasi terhadap Kinerja Karyawan.

Motivasi merupakan sebuah keahlian dalam mengarahkan karyawan pada tujuan organisasi agar mau bekerja dan berusahan sehingga keinginan para karyawan dan tujuan organisasi dapat tercapai. Menurut (Badjamal, 2019) Motivasi seseorang melakukan suatu pekerjaan karena adanya suatu kebutuhan hidup yang harus dipenuhi. Kebutuhan ini berupa kebutuhan ekonomis yaitu memperoleh uang, sedangkan kebutuhan nonekonomis dapat diartikan sebagai kebutuhan untuk memperoleh penghargaan dan keinginan lebih maju. Dengan segala kebutuhan tersebut, seseorang dituntut untuk lebih giat dan aktif dalam bekerja, untuk mencapai hal ini diperlukan adanya motivasi dalam melakukan pekerjaan, karena dapat mendorong seseorang bekerja dan selalu berkeinginan dan melanjutkan usahanya. Oleh karena itu jika karyawan yang mempunyai motivasi kerja yang tinggi biasanya mempunyai kinerja yang tinggi pula. Suharto dan Cahyono (2005) dan Hakim (2006) menyebutkan ada salah satu factor yang mempengaruhi kinerja yaitu faktor motivasi, dimana motivasi merupakan kondisi yang menggerakan seseorang berusaha untuk mencapai tujuan atau mencapai hasil yang diinginkan. Rivai (2004) menunjukan bahwa semakin kuat motivasi kerja, kinerja karyawan akan semakin tinggi. Hal ini berarti bahwa setiap peningkatan motivasi kerja pegawai akan memberikan peningkatan yang sangat berarti bagi peningkatan kinerja pegawai dalam melaksanakan pekerjaannya.

2) Pengaruh Disiplin Kerja terhadap Kinerja Karyawan

Disiplin sangat dekat kaitannya dengan performance kerja. Dalam suatu kajian keilmuan, disiplin dapat dipandang sebagai suatu pemahaman teoritis yang menuntut wujud aplikasinya secara mental terhadap karyawan atau siapapun yang menjadi bagian dari suatu instansi atau pun organisasi.Berbagai kajian teoritis sering mengkaitkan disiplin dengan suatu hal yang penuh isyarat hukum dan komitmen antar bagian dan individu dalam suatu organisasi. Namun hal yang tidak dapat dipungkiri adalah disiplin adalah sesuatu yang menjadi bagian pokok atau faktor penentu keberhasilan pencapaian tujuan organisasi/instansi ataupun tujuan individu. Atas pemikiran tersebut, penulis mencoba mengangkat suatu pemahaman tentang arti penting disiplin dalam suatu organisasi dan individu.Dalam penulisan ini, materi pembahasan diarahkan pada objek karyawan sebagai pelaku utama dalam suatu organisasi/perusahaan.

Menurut Sutrisno (2009), menyatakan bahwa disiplin kerja adalah sikap kesediaan dan kerelaan seseorang untuk mematuhi dan mentaati segala norma peraturan yang berlaku di organisasi. Disiplin pegawai yang baik akan mempercepat pencapaian tujuan organisasi artinya jika disiplin pegawai yang baik akan menghasilkan kinerja baik juga, sedangkan disiplin yang merosot akan menjadi penghalang dan memperlambat pencapaian tujuan organisasi

3) Pengaruh Lingkungan Kerja terhadap Kinerja Karyawan.

Lingkungan kerja dapat memengaruhi emosional karyawan Jika karyawan menyenangi lingkungan kerjanya maka karyawan tersebut akan betah di tempat kerjanya, melakukan aktifitasnya sehingga waktu kerja dipergunakan secara efektif. Produktifitas akan tinggi dan prestasi kerja karyawan juga tinggi. Lingkungan kerja dapat diartikan sebagai kekuatan-kekuatan yang memengaruhi, baik secara langsung maupun tidak langsung terhadap kinerja organisasi atau perusahaan.Menurut Sedarmayati bahwa lingkungan kerja adalah keseluruhan alat perkakas dan bahan yang dihadapi, lingkungan sekitarnya dimana seseorang bekerja, metode kerjanya, serta pengaturan kerjanya, baik sebagai perseorangan maupun sebagai kelompok. 
Menurut Mangkunegara (2004:68), lingkungan kerja mempunyai hubungan yang sangat erat terhadap kinerja pegawai, motif berprestasi yang perlu dimiliki oleh pegawai harus ditumbuhkan dari dalam diri sendiri dan dari lingkungan kerja, karena motif berprestasi yang ditumbuhkan dari dalam diri sendiri akan membentuk suatu kekuatan diri dan jika situasi lingkungan kerja turut menunjang maka pencapaian kinerja akan lebih mudah.

\section{METODE PENELITIAN}

Metode penelitian merupakan cara yang digunakan oleh peneliti dalam mengumpulkan data penelitiannya. Metode dalam penelitian ini menggunakan metode deskriptif dan verifikatif, yaitu hasil penelitian yang kemudian diolah dan diambil kesimpulannya. Dengan menggunakan metode penelitian akan diketahui hubungan yang signifikan antara variabel yang diteliti sehingga menghasilkan kesimpulan yang akan memperjelas gambaran mengenai objek yang diteliti (Sugiono; 2010).

Lokasi penelitian dilaksanakan pada Dinas Pendidikan Kota Palu. Penelitian ini di lakukan pada dari bulan Maret sampai Mei 2019.

\section{Populasi}

Populasi (universe) menurut Sugiyono (2001; 55) merupakan wilayah generalisasi yang terdiri atas objek atau subjek yang mempunyai kualitas dan karakteristik tertentu yang ditetapkan oleh peneliti untuk dipelajari dan menarik kesimpulan. Adapun jumlah populasi pada penelitian ini yaitu sebanyak 103 pegawai terdiri dari 4 bidang.

\section{Sampel}

Sugiyono (2001; 56). Sampel adalah sebagian dari jumlah dan karakteristik yang dimiliki oleh populasi.Penentuan besarnya sampel dilakukan dengan menggunakan formulasi rumus Slovin yang dikemukakan oleh Taro Yamane Dengan demikian, dari sebanyak populasi yang ada, diambil sebanyak 51 responden.

\section{HASIL DAN PEMBAHASAN}

\section{Uji asumsi klasik}

Pengujian ini dilakukan dengan maksud untuk mengetahui apakah model regresi linear berganda yang digunakan dalam menganalisis aspek yang diteliti pada sebuah objek penelitian telah memenuhi kriteria asumsi klasik, sehingga hasilnya mampu memberikan jaminan terhadap peramalan yang terbaik ke depan.

\section{Uji Multikolinearitas}

Uji multikolinearitas dimkasudkan untuk mengetahui apakah diantara variabel bebas (independen) tidak saling berkorelasi atau tidak terdapat hubungan yang signifikan antara variabel. Menurut Gunawan $(2001 ; 235)$ untuk mendeteksi adanya Multikolinearitas dapat dilihat dari besaran VIF (Variance Inflantion Faktor) kurang dari 10 dan Tolerance lebih besar dari angka 0,10 serta koefisien antara variabel independen dibawah 0,5 maka dapat disimpulkan tidak terjadi Multikolinearitas.

Tabel 1

Uji Multikolinieritas

\begin{tabular}{|c|c|c|c|}
\hline \multirow{2}{*}{ No } & \multirow{2}{*}{ Variabel } & \multicolumn{2}{|c|}{ Collinearity Statistik } \\
\cline { 3 - 4 } & & Tolerance & VIF \\
\hline 1 & Komunikasi & .543 & 1.842 \\
\hline 2 & Motivasi & .556 & 1.797 \\
\hline 3 & $\begin{array}{c}\text { Lingkungan } \\
\text { Kerja }\end{array}$ & .365 & 2.739 \\
\hline
\end{tabular}

Sumber: Data primer diolah

Tabel 1. memperlihatkan semua nilai variabel independen untuk tolerance $>0,1$ dan VIF $<10$, hal ini berarti tidak terjadi multikolinieritas.

\section{Heterokedastisitas}

Uji heterokedastisitas dilakukan untuk menguji apakah dalam sebuah model regresi telah terjadi ketidaksamaan varian dari residual atas suatu pengamatan ke pengamatan lainnya.Jika variannya tetap, maka model regresi tersebut berada pada kondisi homoskadensitas (Husein Umar, 2003; 137).Uji ini dilakukan dengan menggunakan residual plot (scatter plot). 


\section{Iumal ERonomi Trend Vol. 09 SNo. 01 Januari - Juni 2021 E-ISST. 2722-6565}

Untuk mendeteksi adanya heterokedastisitas dilakukan dengan melihat ada tidaknya pola tertentu dalam grafik, dimana sumbu $\mathrm{X}$ adalah $\mathrm{Y}$ yang telah diprediksi, dan sumbu $X$ adalah residual yang telah di studentized. Dasar pengambilan keputusan:

Jika ada pola tertentu, seperti titik-titik (poin-poin) yang ada membentuk suatu pola tertentu yang teratur (bergelombang, melebar kemudian menyempit), maka telah terjadi heteroskedastisitas.

Jika tidak ada pola yang jelas, serta titiktitik yang menyebar diatas dan dibawah angka 0 pada sumbu Y, maka tidak terjadi heteroskedastisitas.

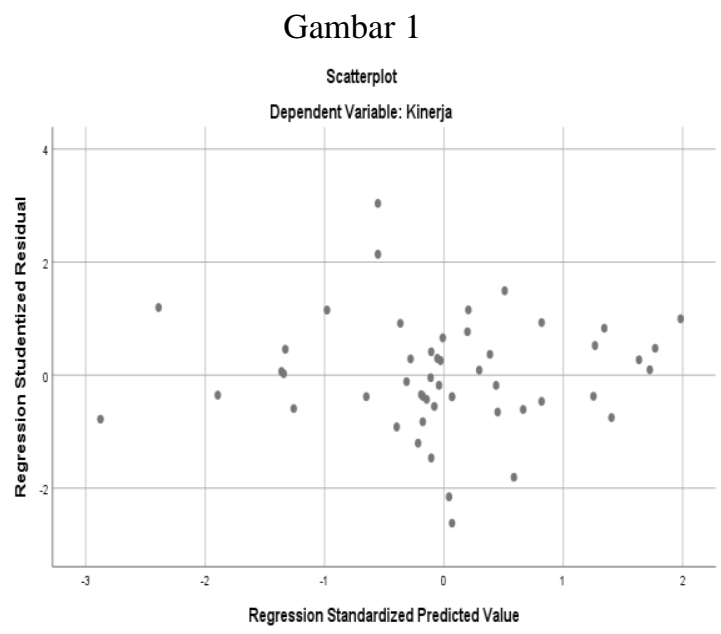

\section{Normalitas}

Uji normalitas bertujuan untuk mengetahui apakah data dalam model regresi antara variabel independen dan variabel dependen keduanya berdistribusi normal atau tidak normal.Model data yang baik adalah berdistribusi normal atau mendekati normal yang membentuk suatu garis lurus diagonal dari sudut kiri bawah ke sudut kanan atas. Deteksi normalitas dilakukan dengan melihat penyebaran data (titik) pada sebuah diagonal dari grafik dengan dasar pengambilan keputusan adalah sebagai berikut (Santoso, 2002; 214):

1. Jika data menyebar disekitar garis diagonal, maka model regresi memenuhi asumsi normalitas.
2. Jika data menyebar jauh dari garis diagonal, dan atau tidak mengikuti garis diagonal, maka model regresi tidak dapat memenuhi asumsi normalitas.

Gambar 2

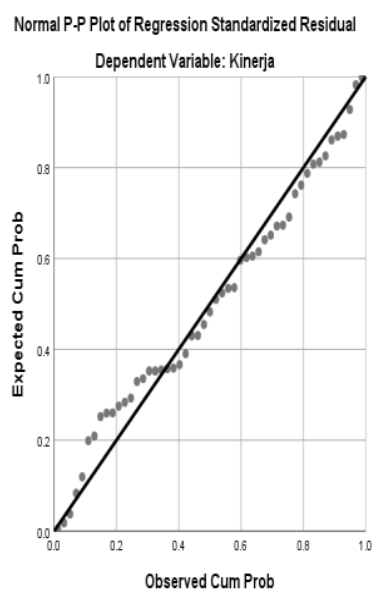

\section{Hasil Pengujian Regresi}

Analisis regresi linear berganda dalam penelitian ini digunakan untuk mengetahui pengaruh variabel komunikasi, disiplin kerja, dan budaya organisasi terhadap kinerja Pegawai Dinas Pendidikan Kota Palu berdasarkan pengujian diperoleh hasil sebagai berikut:

Tabel 2

Hasil Pengujian Regresi Linear Berganda

\begin{tabular}{|l|r|r|r|}
\hline \multicolumn{4}{|c|}{ Faktor Terikat $=$ Kinerja (Y) } \\
\hline \multicolumn{1}{|c|}{ Variabel } & (Beta) & \multicolumn{1}{c|}{ t-hit } & Sig.t \\
\hline (Constant) & .346 & .081 & .936 \\
Motivasi (X1) & .896 & 10.070 & .000 \\
Disiplin (X2) & .515 & 3.607 & .001 \\
Lingkungan Kerja(X3) & .326 & 2.746 & .009 \\
\hline $\mathrm{n}=42$ & & \\
Konstanta = .346 & & \\
Koefesien Korelasi (R) $=.886$ & \\
Koefisien Determinasi $\left(\mathrm{R}^{2}\right)=.786$ & \\
F-Statistik $=57.406$ & \\
Sig.F $=.000$ & \\
\hline
\end{tabular}

Dari hasil pengujian dengan menggunakan regresi linier berganda di atas, maka dapat disusun persamaan regresi berganda dari pengaruh komunikasi, disiplin kerja, dan 
budaya organisasi terhadap kinerja Pegawai Dinas Pendidikan Kota Paluyaitu:

$$
\mathrm{Y}=0.346+0.896 \mathrm{X} 1+0.515 \mathrm{X} 2+0.326 \mathrm{X3}
$$

Persamaan diatas menunjukkan, variabel independen yang dianalisis berupa variabel (X1, $\mathrm{X} 2$,dan X3) memberi pengaruh terhadap variabel independen $(\mathrm{Y})$.

Dari persamaan di atas dapat dijelaskan;

1. Untuk nilai constanta 346 sebesar berarti kinerja pegawai pada Dinas pendidikan Kota Palu sebelum adanya variabel independen adalah sebesar 346 .

2. Motivasi (X1) dengan koefisien regresi .896 ini berarti terjadi pengaruh yang negative antara komunikasi dan kinerja pegawai pada Dinas pendidikan Kota Palu. Artinya jika terjadi komunikasi yang baik yang terjadi pada Kantor Dinas pendidikan Kota Palu. Maka akan meningkatkan kinerja Pegawaipada Dinas pendidikan Kota Palu.

3. Disiplin (X2) dengan koefisien regresi .515 ini berarti terjadi pengaruh yang positif antara disiplin dan kinerja pegawai pada Dinas pendidikan Kota Palu. Artinya semakin baik motivasi pegawai pada Dinas pendidikan Kota Palu maka akan menaikkan kinerja pegawai pada Dinas pendidikan Kota Palu.

4. Lingkungan kerja $\left(\mathrm{X}_{3}\right)$ dengan koefisien regresi .326 ini berarti terjadi pengaruh yang positif antara lingkungan kerja dan kinerja pegawai pada Dinas pendidikan Kota Palu. Artinya semakin baik lingkungan kerja yang ada di lingkungan Dinas pendidikan Kota Palu maka akan menaikkan kinerja Pegawai pada Dinas pendidikan Kota Palu.

$\mathrm{R}$ Square atau koefisien determinasi $\left(\mathrm{R}^{2}\right)$ adalah melihat pengaruh antara variable komunikasi, disiplin kerja dan budaya organisasi terhadap kinerja pegawai Dinas Pendidikan Kota Palusebesar 0.786 atau $78,6 \%$ artinya pengaruh variabel bebas (independen) terhadap variabel terikat (dependen) sebesar 78,6\% sedangkan sisanya $21,4 \%$ adalah pengaruh variabel lain yang tidak diteliti dalam penelitian ini.

\section{Pembuktian Hipotesis}

Pembuktian Hipotesis Pertama

Hipotesis pertama yaitu pengaruh motivasi, disiplin dan lingkungan kerja secara serempak berpengaruh signifikan terhadap kinerja Dinas pendidikan Kota Palu. Pembuktian hipotesis pertama menggunakan

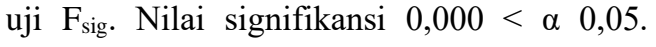
Maka terbukti ketiga variabel bebas yaitu motivasi, disiplin dan lingkungan kerja secara serempak berpengaruh signifikan terhadap kinerja pegawai Dinas pendidikan Kota Palu. Hal ini menunjukkan hipotesis pertama dapat diterima.

Pembuktian Hipotesis Kedua

Hipotesis kedua yaitu untuk mengetahui apakah variabel motivasi berpengaruh signifikan terhadap kinerja pegawai Dinas pendidikan Kota Palu. Tabel di atas terbukti besarnya probabilitas signifikansi variabel harga (X1) adalah .000 < taraf signifikan yang diisyaratkan $\alpha 0,05$. Dengan demikian bahwa secara statistik variabel motivasi dalam penelitian ini memberikan pengaruh signifikan terhadap terhadap kinerja pegawai Dinas pendidikan Kota Palu. Hal ini menunjukkan hipotesis kedua dapat diterima.

Pembuktian Hipotesis Ketiga

Hipotesis ketiga yaitu untuk mengetahui apakah variabel disiplin berpengaruh signifikan terhadap kinerja pegawai Dinas pendidikan Kota Palu. Tabel di atas terbukti besarnya probabilitas signifikansi variabel disiplin kerja (X2) adalah .001 < taraf signifikan yang diisyaratkan $\alpha 0,05$. Dengan demikian bahwa secara statistik variabel disiplin dalam penelitian ini memberikan pengaruh signifikan terhadap kinerja pegawai Dinas pendidikan Kota Palu. Hal ini menunjukkan hipotesis ketiga dapat diterima.

Pembuktian Hipotesis Keempat

Hipotesis keempat yaitu untuk mengetahui apakah variabel lingkungan kerja berpengaruh signifikan terhadap kinerja Dinas pendidikan Kota Palu. Tabel di atas terbukti besarnya probabilitas signifikansi 
variabel lingkungan kerja (X3) adalah .009< taraf signifikan yang diisyaratkan $\alpha 0,05$. Dengan demikian bahwa secara statistik variabel lingkungan kerja dalam penelitian ini memberikan pengaruh signifikan terhadap kinerja pegawai Dinas pendidikan Kota Palu. Hal ini menunjukkan hipotesis keempat dapat diterima.

\section{Pembahasan}

Hasil pembuktian hipotesis dalam penelitian ini pengaruh motivasi, disiplin dan lingkungan kerja terhadap kinerja pegawai Dinas pendidikan Kota Palu memberikan pembuktian bahwa ketiga variabel independen yaitu motivasi, disiplin dan lingkungan kerja berpengaruh signifikan terhadap kinerja pegawai Dinas pendidikan Kota Palu. Dengan demikian dinyatakan bahwa hipotesis mengenai pengaruh motivasi, disiplin dan lingkungan kerja terhadap kinerja pegawai Dinas pendidikan Kota Palu dapat diterima.

\section{Pengaruh Motivasi, Disiplin Dan Lingkungn Kerja Terhadap Kinerja Pegawai Dinas Pendidikan Kota Palu.}

Berdasarkan hasil analisis data yang telah diuraikan sebelumnya, menujukkan bahwa variabel motivasi, disiplin dan lingkungan kerja secara bersama-sama berpengaruh signifikan terhadap kinerja pegawai pada Hasil tersebut mengindikasikan bahwa motivasi, disiplin dan lingkungan kerja dapat meningkatkan kinerja pegawai pada Dinas pendidikan Kota Palu, hal ini bermakna bahwa hipotesis yang diuraikan sebelumnya sejalan dengan hasil penelitian ini.

Hasil penelitian ini menujukan bahwa motivasi kerja juga mempunyai pengaruh signifikan terhadap kinerja Pegawai Dinas Pendidikan Kota Palu. Faktor motivasi kerja menjadi salah satu pendorong seseorang dalam meningkatkan kinerjanya, sehingga tidak jarang ditemukan dalam sebuah organisasi yang berkinerja cukup baik disebabkan karena motivasi kerja para pegawai yang ada di dalam organisasi tersebut.
Faktor kedisiplinan juga memegang peranan penting dalam meningkatkan kinerja pegawai.Kedisiplinan merupakan salah satu tolak ukur bagi seorang pegawai yang bekerja di suatu organisasi. Seorang pegawai yang disiplin akan melakukan pekerjaan yang diberikan kepadanya tanpa harus menunggu perintah dari atasannya. Upaya dalam peningkatan kinerja Pegawai Dinas Pendidikan Kota Palu, tidak terlepas dari bagaimana meningkatkan kedisiplinan pegawai pada Dinas Pendidikan Kota Palu, sehingga dapat menjadikan Dinas Pendidikan Kota Palu yang memberikan pelayanan publik secara maksimal.

Hasil penelitian ini menujukan bahwa kinerja juga mempunyai pengaruh signifikan terhadap kinerja Pegawai Dinas Pendidikan Kota Palu. Faktor lingkungan kerja menjadi salah satu pendorong seseorang dalam meningkatkan kinerjanya, sehingga tidak jarang ditemukan dalam sebuah organisasi yang berkinerja cukup baik disebabkan karena lingkungan kerja yang membuat nyaman para pegawai yang ada di dalam organisasi tersebut.

\section{Keterkaitan Motivasi Terhadap Kinerja Pegawai Dinas Pendidikan Kota Palu.}

Hasil penelitian menunjukkan bahwa besarnya pengaruh variabel bebas motivasi yang terdiri dari lima indikator yaitu aktualisasi diri, penghargaan, kebutuhan sosial, kebutuhan rasa aman, dan kebutuhan fisik, dengan hasil perhitungan nilai koefisien regresi sebesar 0,896, dengan tingkat signifikasi sebesar 0,000. Dengan demikian Sig $\mathrm{t}<0,05$ pada taraf kepercayaan $95 \%$. Sehingga dapat dinyatakan bahwa varaibel motivasi mempunyai pengaruh yang signifikan terhadap kinerja Pegawai Dinas Pendidikan Kota Palu

Berdasarkan tabel 4.5 di atas dapat diketahui presentase rat-rata tanggapan dari 51 responden terhadap 12 pernyataan yang diajukan terkait dengan variabel motivasi (X1), dideskripsikan berdasarkan masing-masing pernyataan nilai mean tertinggi dan terendah pada pernyataan. Dari dua belas pernyataan yang dijadikan sebagai alat ukur terhadap motivasi teryata pernyataan Saran dan kritik yang diberikan 
oleh pimpinan membuat saya lebih maju. memiliki rata-rata jawaban responden tertinggi dibandingkan dengan pernyataan lainnya pada variabel motivasi dengan nilai mean 4.4314 itu artinya skala intervalnya tergolong sangat baik. Dari tiga belas pernyataan Saran dan kritik yang diberikan oleh pimpinan membuat saya lebih maju. memiliki nilai rata-rata mean 3.6667 meski masih tergolong skala intervalnya skala intervalnya dalam kategori baik.

Pengaruh Disiplin Terhadap KinerjaPegawai Dinas Pendidikan Kota Palu.

Hasil penelitian menunjukkan bahwa besarnya pengaruh variabel bebas disiplin yang terdiri dari delapan pernyataan dengan hasil perhitungan nilai koefisien regresi sebesar 0,515, dengan tingkat signifikasi sebesar 0,001. Dengan demikian nilai Sig t $<0,05$ pada taraf kepercayaan 95\%. Sehingga dapat dinyatakan bahwa varaibel disiplin kerja mempunyai pengaruh yang signifikan terhadap kinerja Pegawai Dinas Pendidikan Kota Palu.

Berdasarkan Tabel di atas dapat diketahui presentase rata-rata tanggapan dari 51 responden terhadap 8 pernyataan yang diajukan terkait dengan variabel Disiplin Kerja (X2), dideskripsikan berdasarkan masing-masing indikator nilai mean tertinggi dan terendah pada pernyataan. Dari delapan pernyataan yang dijadikan sebagai alat ukur terhadap disiplin kerja ternyata pernyataan atasan akan memberikan teguran apabila pekerjaan tidak dapat diselesaikan memiliki rata-rata jawaban responden tertinggi dibandingkan dengan pernyataan lainnya pada variabel disiplin kerja dengan nilai mean $\mathbf{4 . 5 2 9 4}$ itu artinya nilai skala intervalnya tergolong sangat baik. Dari delapan pernyataan disiplin kerja pernyataan Sistem pendataan kehadiran di organisasi sudah efektif dan Izin dari atasan diperlukan apabila karyawan hendak meninggalkan lingkungan kerja memiliki nilai rata-rata mean terendah sebesar $\mathbf{4 . 2 7 2 5}$ meski masih tergolong skala intervalnya dalam kategori sangat baik.
Pengaruh Lingkungan Kerja Terhadap Kinerja Pegawai Dinas Pendidikan Kota Palu.

Hasil penelitian menunjukkan bahwa besarnya pengaruh variabel bebas lingkungan kerja yang terdiri dari dua belas pernyataan dengan hasil perhitungan nilai koefisien regresi sebesar 0,326 dengan tingkat signifikasi sebesar 0,009. Dengan demikian Sig $\mathrm{t}<0,05$ pada taraf kepercayaan 95\%. Sehingga dapat dinyatakan bahwa varaibel lingkungan kerja mempunyai pengaruh yang signifikan terhadap kinerja Pegawai Dinas Pendidikan Kota Palu..

Berdasarkan tabel di atas dapat diketahui presentase rat-rata tanggapan dari 51 responden terhadap 12 pernyataan yang diajukan terkait dengan variable lingkungan kerja (X3), dideskripsikan berdasarkan masing-masing pernyataan nilai mean tertinggi dan terendah pada pernyataan. Dari duabelas pernyataan yang dijadikan sebagai alat ukur terhadap lingkungan kerja teryata pernyataan prosedur kerja menjamin keselamatan saya ketika bekerja memiliki rata-rata jawaban responden tertinggi dibandingkan dengan pernyataan lainnya pada variable lingkungan kerja dengan nilai mean $\mathbf{4 . 4 1 1 8}$ itu artinya skala intervalnya tergolong sangat baik. Dari dua belas pernyataan Serkulasi udara di tempat kerja membuat saya bernafas dengan oksigen yang cukup memiliki nilai rata-rata mean $\mathbf{3 . 6 8 6 3}$ meski masih tergolong skala intervalnya skala intervalnya dalam kategori baik.

\section{KESIMPULAN}

Berdasarkan hasil penelitian dan pembahasan dengan menggunakan metode analisis regresi berganda, dapat disimpulkan sebagai berikut;

1. Motivasi, Disiplin dan lingkungan kerja organisasi secara serempak berpengaruh positif terhadap kinerja Pegawai Dinas Pendidikan Kota Palu.

2. Motivasi berpengaruh positif dan signifikan terhadap kinerja kinerja Pegawai Dinas Pendidikan Kota Palu.

3. Disiplin berpengaruh positif dan signifikan terhadap kinerja kinerja Pegawai Dinas Pendidikan Kota Palu. 
4. Lingkungan Kerja berpengaruh positif dan signifikan terhadap kinerja kinerja Pegawai Dinas Pendidikan Kota Palu.

\section{SARAN}

1. Komunikasi merupakan variabel yang berpengaruh terhadap kinerja Aparatur Sipil Negara Badan Kepegawaian Daerah Provinsi Sulawesi Tengah, berarti komunikasi merupakan salah satu hal yang sangat penting bagi kinerja pegawai , seyogyanya bagi pimpinan agar terus meningkatkan komunikasinya dan tetap memperhatikan secara terus menerus dengan tidak melupakan variabel lain yang juga sama penting.

2. Disiplin kerja merupakan hal yang sangat penting bagi pegawai didalam menjalankan tugas atau pekerjaan. Berdasarkan pengamatan dilapangan kondisi sebagian pegawai tidak menaati peraturan yang ditetapkan instansi. Hal itu terlihat dengan masih adanya pegawai yang masuk terlambat kerja, pulang tidak sesuai waktu, selain itu pegawai sering mengulur waktu istirahat, masih adanya perilaku pegawai yang tidak menaati peraturan instansi. Apabila hal ini terus-menerus, maka dapat merugikan bagi instansi.

3. Lingkungan kerja berpengaruh positif dan signifikan pada semangat kerja pegawai kantor desa se kecamatan Patebon. Semangat kerja pegawai akan tercipta ketika semua fasilitas yang dibutuhkan pegawai untuk menyelesaikan pekerjaan telah terpenuhi dengan baik, serta terciptanya lingkungan yang nyaman untuk bekerja, seperti penerangan, pewarnaan, kebersihan, pertukaran udara, keamaan, fasilitas penunjang pekerjaan, dan hubungan yang baik antar sesama pegawai.

\section{DAFTAR PUSTAKA}

Anwar Prabu Mangkunegara (2005) Manajemen sumber daya manusia, Bandung.

Badjamal, F. A. (2019). PENGARUH GAYA HIDUP DAN EKUITAS MEREK TERHADAP KEPUTUSAN PEMBELIAN HANPHONE MEREK SAMSUNG DI KOTA PALU. Jurnal Ekonomi Trend, 7(2), 1-11. https://doi.org/10.31970/trend.v7i2.175

Bahctiar (2012). Pengaruh motivasi dan lingkungan kerja terhadap kinerja karyawan study PT. Aqua Tirta Ivestama di Klaten.

Buhler, Patricia. 2004. Alpa Teach Yourself. Management Skil, Prenada Media Jakarta.

Dwi Priyanto, 2009. Mandiri Belajar Dengan Program SPSS, Jakarta

Edy Sutrisno, 2014. Manajemen Sumber Daya Manusia. Pranada Media Group, Jakarta.

Edy Sutrisno, (2011) Manajemen Rumber Daya Manusia, Pranada Media Group, Jakarta

Gulom, M. (2019). PENGARUH KOMPETENSI, DISIPLIN DAN LINGKUNGAN KERJA TERHADAP MUTU PELAYANAN PADA BANK PEMBANGUNAN DAERAH KABUPATEN TOJO UNAUNA. Jurnal Ekonomi Trend, 7(2), 42-47. https://doi.org/10.31970/trend.v7i2.179

Ghozali, Imam. (2006) Aplikasi Analisis Multivariate Dengan Program SPSS. Cetakan Keempat. Semarang: Badan Penerbit Universitas Diponegoro

Handoko, T Hani. (2001). Manajemen Personalia dan Sumberdaya Manusia, Yogyakarta

Hasiabuan, Malayu S,P (2003) Manajemen Sumber Daya Manusia, Jakarta

Hasibuan, Malayu. 2013. Manajemen Sumber Daya Manusia. Jakarta. 
Marjun, M. (2019). PENGARUH DI MENSI DIMENSI KUALITAS LAYANAN TERHADAP KEPUASAN PASIEN RAWAT INAP BPJS KESEHATAN CENTER RUMAH SAKIT UMUM DAERAH ANUTAPURA. Jurnal Ekonomi Trend, 7(1), 12-26. https://doi.org/10.31970/trend.v7i1.170

Moekijat. (1999). Manajemen Sumber Daya Manusia (Manajemen Kepegawaian), Penerbit Mandar Maju. Bandung.

Notoatmodjo, Soekidjo (2009) Pengembangan sumber daya manusia, Jakarta Rineka Cipta.

Pangkabean, Mutiara, (2007), Manajemen Sumber Daya Manusia, Bogor, Ghalia Indonesia

Robbins Stephen P. 2006. Perilaku Organisasi,Jakarta

Rivai, Veithzal. (2011), Manajemen Sumber Daya Manusia untuk Perusahaan, Jakarta.

Rangkuti, Freddy. (1997). Analisis SWOT Teknik Membedah Kasus Bisnis. Jakarta.

Subroto .2005. Proses Belajar Mengajar di Sekolah. Jakarta: Rineka Cipta.

Sedarmayanti. (2004), Sumber Daya Manusia dan Produktivitas Kerja. Bandung: Mandar Maju

Sastrodiningrat, A.G., 2007. Pemahaman Indikator-Indikator Dini dalam Menetukan Prognosa Cedera Kepala Berat, Medan

Sugiyono (2001), Metode Penelitian Administrasi, Penerbit Alfabeta Bandung

(2012) Memahami Penelitian Kualitatif, Bandung

Santoso, Singgih. (2001). Mengolah Data Statistik Secara Profesional. PT. Alex Media Komputindo. Jakarta. 